\title{
National Learning, National Literature, and National Language
}

\section{Qingshen Tong}

\section{(2) OpenEdition \\ 12 Journals}

Electronic version

URL: http://journals.openedition.org/chinaperspectives/5376

DOI: 10.4000/chinaperspectives.5376

ISSN: 1996-4617

\section{Publisher}

Centre d'étude français sur la Chine contemporaine

\section{Printed version}

Date of publication: 1 January 2011

Number of pages: 33-38

ISSN: 2070-3449

\section{Electronic reference}

Qingshen Tong, " National Learning, National Literature, and National Language », China Perspectives [Online], 2011/1 | 2011, Online since 30 March 2014, connection on 28 October 2019. URL : http:// journals.openedition.org/chinaperspectives/5376; DOI : 10.4000/chinaperspectives.5376 


\title{
National Learning, National
}

\section{Literature, and National Language}

\author{
QINGSHENG TONG*
}

\begin{abstract}
This essay is a critical reaction to the movement for the revival and constitution of guoxue (national learning), not just as a system of indigenous knowledge and scholarship, but also as an embodiment of Chinese national culture. Situating the conceptualisation of guoxue in the context of the May Fourth new cultural movement, the essay attempts to show: a) that guoxue is a category devoid of substance, not least because its classificatory scope cannot be adequately defined, b) that guoxue was invented in the early twentieth century in response to the pressures created by the influx of Western learning that had begun to unsettle and displace forms of classical learning, and c) that the idea of guoxue is rooted in the conviction of the singularity of national culture. Historically, guoxue has opposed such national projects as national language and national literature. Revisiting a selection of representative views of progressive May Fourth and communist intellectuals on the need to develop and construct a new national language and literature for China's modernisation, the essay argues for the need to develop a historical understanding of the process in which classical learning has been displaced and to recognise the importance of this process for the development of China's intellectual modernity.
\end{abstract}

KEYWORDS: National learning, national language, national literature, intellectual modernity, third-world intellectuals

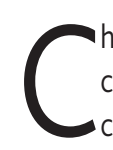
hina's economic rise in recent years has brought about conditions conducive to the emergence of a structure of nationalistic feeling comprised of the desire to build and develop "soft power" commensurate with its rising international stature. There might be disagreement as to what exactly constitutes a nation's soft power, but in the context of China's rapid development into a global power, recent discursive efforts to recover, retrieve, and reinstate its cultural past, in particular the movement to revive guoxue (national learning), are no doubt part of an ambitious project to develop and consolidate its intellectual indigeneity and thereby its cultural identity.

In the first decade of this century, especially since 2005 , the term guoxue has rapidly become a focus of attention, not just within the academy or among the academic and political elites, but also in the public domain, in the visual and print media, as an arena of ideological contest and a site of self-affirmation. (1) In November 2009, for example, Tsinghua University held a major public launch of its Academy of Chinese Learning (Guoxue yanjiu yuan), an event worth noting in particular because of its unmistakable historical resonance with the short-lived Tsinghua guoxue yanjiu yuan (1925 - 1929), and its claim to a historical past that would lend credence and prestige to the present and to a lost institutional glory that might be employed to reassert its institutional centrality in humanistic studies. ${ }^{(2)}$

The movement to revive guoxue and to constitute it as the system of learning that is uniquely and quintessentially Chinese carries an irony, in that it begins with an acknowledgment of guoxue's marginality, an acknowledgement that nevertheless could be strategically employed to validate and legitimate the need and value of guoxue at the present time. Why should special efforts be made to reinstate something if it had been functional and active? Why would the nation as a whole need to be mobilised at this juncture for guoxue's reinstatement had it not been in crisis? Guoxue exponents must not evade an historical understanding of the crisis that major forms of classical learning necessarily experienced in the early twentieth century. It is indeed on the agenda of the guoxue movement to revalorise May Fourth cultural radicalism and to some extent the Chinese revolution, even though this would push the whole debate on the idea and need of guoxue beyond the limits of its own conceptualisation as a system of learning or scholarship. This is not to say that May Fourth should not or could not be reconsidered, revalorised, or even critiqued. But unless it could be decisively shown to be a destructive or negative social, cultural, and intellectual movement in the nation's search and struggle for modernity, not just as an idea, but as a project or program of social construction, the call for the revival and reconstitution of guoxue must not keep silent about or simply ignore the socio-historical forces that displaced it in the first instance. National emancipation was imagined by May Fourth intellectuals in terms of such national projects as national literature and national language, which for them could only be brought into being at the cost of classical cultural and intellectual formations such as guoxue. Nearly a century later, the efforts to reconstruct guoxue is at once an act of defence and offense, a statement of the need for guoxue as an articulation of intellectual Chineseness and a repudiation of the forces that have undermined its hegemony and displaced its centrality. But it would be a difficult task to mediate between the perceived desir-

Qingsheng Tong teaches in the School of English, University of Hong Kong. He has published on issues of critical significance in comparative studies, with special attention to the historical interactions between China and the West. His current work focuses on the Chinese language reform movement in the early twentieth century and its social and political consequences.

1. For a review of the concept and practice of guoxue in the twentieth century, see Liu Mengxi, "Lun guoxue" (On national learning), in On Guoxue, Shanghai, Shanghai remin chubanshe, 2008, pp. 11-56.

2. It is difficult to establish any genuine relationship between the two, not least because they are separated by a hiatus of more than 80 years and are the products of two different sets of historical conditions. The perceived continuity between them is that both are committed to studying and promoting the "spirit of China." See "Qinghua daxue chengli guoxue yanjiu yuan," 2 November 2009 (consulted 24 March 2010), http://news.tsinghua.edu.cn/new/ news.php?id=21505. 
ability of guoxue and the historical demands that it be removed and replaced with a different system of learning.

\section{Classification of guoxue}

The term guoxue poses difficulties as well as questions about its genealogical and classificatory validity. Crucial for its conceptualisation as a system of learning or scholarship is the availability of its typological organisation and its internal taxonomy; a classificatory delineation of guoxue as a system of learning is necessary for its formalisation - for it to have a form, a structure, and a procedure enabling students, critics and genealogists to engage with it. The question of what guoxue is, therefore, is intertwined with its genealogical and socio-historical formation.

The term guoxue has been in use for over 2,000 years, but as is often the case, the etymological roots of the modern term do not attest its present usage. In its classical usage, guoxue refers to an official centre of learning, an imperial academy, a courtly site for production of officially-sanctioned knowledge, especially dynastical historiography, and a shrine that both preserved and distributed classical learning and traditional scholarship. In its contemporary usage, however, it refers to a conceptual categorisation for the totality of learning and scholarship that is perceived or considered to be Chinese and, by implication, to be distinct from other systems of learning, especially Western learning. The semantic discontinuity between its etymological origin and its present usage is manifest. Deng Shi, probably the first to propose the idea of guoxue, is frequently quoted for a description of guoxue's modern etymological beginning. In a 1906 essay "Notes on Guoxue," Deng wrote: "What is national learning? It is the totality of a nation's learning. A nation is formed by those living in the same territory. Where there is a nation there is national learning." (3) Defined as such, the conception of guoxue remains devoid of substance and offers no clear sense of its formal constitution or scope. (4) Precisely because it attempts to encompass everything and include all, guoxue is not a "xue," and "national learning" is not a system of learning. ${ }^{(5)}$

Despite discursive efforts to ontologise guoxue, debates on its constitution recurred throughout the twentieth century, and the conspicuous failure to reach a consensus indicates the difficulties and complexities underlying the attempt to define guoxue as a national system of learning. Qian $\mathrm{Mu}$, an accomplished practitioner of classical learning and someone unlikely to be associated with the discursive scepticism about guoxue, was aware of the ambiguity and instability of guoxue as a concept and category. "It is difficult to determine," writes Qian, "what should be included in it and what should be excluded from it." His reservations about the whole enterprise of guoxue are derived from his conviction that the universality of scholarship transcends national boundaries and cultural divides. The very notion of "national learning" for him constitutes a contradiction to the practice of learning: "There should be no national boundaries to divide scholarship. The term 'guoxue' has no historical precedent and is unlikely to be sustained. It is created in response to the demands of a particular time." (6) Qian's intellectual idealisation of knowledge may be problematic in itself, but his conclusion about the universality of learning and therefore the impossibility or undesirability of a system of national learning was shared by many at the time. ${ }^{(7)}$

It is in response to this cosmopolitan notion of knowledge and learning that advocates of guoxue reconfirmed their commitment to an intellectual conservatism that contributed to the rise of cultural nationalism in the early years of the twentieth century. Martin Bernal, in his discussion of Liu
Shipei's notion of "national essence," describes the return to this cultural conservatism in the early twentieth century as one of "deliberate choice," a movement that "transformed the culture into something artificial," (8) "artificial" because it is no longer possible to delineate and delimit the scope of "national essence" in cultural terms or to give it a form and content for its practice and dissemination.

In the early twentieth century, the term guoxue has become associated with a constellation of terms and appellations that begin with the prefix "guo" (nation, national), such as guogu (national heritage), guocui (national essence), and guoyu (national language). (9) These neologisms were mostly imported from Japanese, in response to diverse political and intellectual agendas. Their inclusion in the Chinese lexicon testified to the deepening sense of crisis precipitated by the collapse of established forms of traditional practice at the time. ${ }^{(10)}$ The abolition of the Imperial Civil Examination in 1905 radically altered the institutional and social basis for the production and dissemination of classical learning, and effectively brought to an end the traditional mode of knowledge production and the means of its distribution. Throughout history, the Imperial Examination system had served to produce and preserve the political and intellectual elites whose medium of self-representation and self-affirmation was classical learning. ${ }^{(11)}$ The country's de-

3. Deng Shi, "Guoxue jiangxi ji" (Notes on national learning), Guocui xuebao (Journal of national essence), no. 19, 1906.

4. For an overview of the etymological mutations of the term guoxue, see Lu Yi, ''Guoxue, 'Cuogu,' 'Cuogu xue'" ("National learning," "national heritage" and "studies of national heritage"), in Nanjing Social Sciences, no. 2, 2005, pp. 72-78.

5. See Luo Zhitian, "Guoxue bushi xue" (Guoxue is not a system of learning), Shehui kexue yanjiu (Social sciences studies), no. 1, 2002, pp. 117-121.

6. Qian Mu, "Foreword," Guoxue gailun (An outline of national learning), Beijing, Commercial Press, 1927, (1997), p. 1.

7. Fu Sinian (Fu Suu-nien), for example, was opposed to all forms of national learning, and he was convinced of the need to accept as universal the modern research paradigms. Separating research materials from research methodology, Fu claimed that research materials presented themselves to scholars in a specific cultural locale and could be meaningfully used only if they were examined within a "scientific" (and therefore universally applicable) methodological framework. In "Objectives of the Institute of History and Philology" (1928), Fu outlined his idea of modern knowledge production: "There is only one and the same research method for scientific research in historical and philological studies in the world, and national boundaries should not logically lead to divisions of scholarship." See Fu Sinian, "Lishi yuyan yanjiusuo gongzuo zhi zhiqu," in Ouyang Zesheng (ed.), Fu Sinian Quanji (Collected works of Fu Sinian), Changsha, Hunan jiaoyu chubanshe, vol. 3, 2003, p. 9.

8. Martin Bernal, "Liu Shih-p'ei and National Essence," in Charlotte Furth (ed.), The Limits of Change: Essays on Conservative Alternatives in Republican China, Cambridge, Mass., Harvard UP, 1976, p. 90.

9. Other terms of similar morphological construction include guoshu (national martial arts), guoyi (national medicine), and guohua (national painting). Like guoxue, they were either lifted or adapted from Japanese, and they won widespread currency in the late nineteenth and early twentieth centuries. Guocui, for example, first came into popular use in 1887, and it was closely associated with the "idea that the preservation of national essence" would strengthen the nation. See Martin Bernal, "Liu Shih-p'ei and National Essence," in Charlotte Furth (ed.), The Limits of Change, op. cit., p. 103. These terms express the same spirit committed to resisting against "increasing Westernization" at the time. See Wang Fan-sen, Fu Ssu-nien: A Life in Chinese History and Politics, Cambridge, Cambridge UP, 2000, p. 153.

10. These terms as cultural conceptualisations contributed to the resurgence of intellectual conservatism and cultural nationalism, but some proponents of cultural Chineseness were more nuanced than others. Zhang Taiyan, for example, pushed for the need of the study of guogu (national heritage), partly because the term was perceived to be less nationalistically biased than such terms as guocui (national essence). Although it is defined as a category encompassing all the major areas of scholarly enquiry, guogu acknowledges its temporality as a thing of the past. See Zhang Taiyan, Guogu lunheng (Evaluation of national heritage) (1910). For a discussion of the etymology of guogu, see Lu Yi, "'Cuoxue,' 'Cuogu,' 'Guogu xue',' in Nanjing Social Sciences, no. 2, 2005, pp. 72-78.

11. The history of classical learning must be considered in close relation to that of the literati class as a social formation, as they had defined and privileged each other throughout history. Recent interest in the humanities in China is typically bound up with the idealisation of wenren (literati or men of letters) and with the possibility of constituting a cultural elitism that wenren once embodied. Such nostalgia for an extinct social class is indicative of the discursive force of cultural conservatism in our time, which is continuous with the historical conservatism that the literati class represented. An earlier critique of the literati was given by the first Chinese Ambassador to Britain and France, Guo Songtao, a literatus himself, who considered the Chinese intellectual elite, especially scholar-officials, to be the source of disastrous outbursts of conservativist nationalism, which could be traced back to the Southern Song period (11271279). See Guo Songtao, Diaries, Changsha, Hunan renmin chubanshe, vol. 3, 1981-1983, 375-6. 
feat in the Sino-Japanese War (1895) shocked the literati class into a reluctant conclusion that the examination system that had defined them was a catastrophic failure and that a failed education system had led to a failed state. Yan Fu viewed its abolition as a revolutionary development, one of the most significant historical events, a watershed that marked the end of one form of intellectual practice, but without a credible indigenous substitute. ${ }^{(12)}$ The Imperial Civil Examination was never simply an examination system through which the best qualified candidates might be selected for public service, but a regime of knowledge and a structure of power and control that combined "culture, society and economics with political power." Its demise removed the institutional and social basis of classical learning and was the necessary condition for the emergence of the modern "intellectual" as distinct from the traditional wenren (literatus). ${ }^{(13)}$

The year 1905 was, therefore, a decisive historical disjunction, after which it is no longer possible to speak of the production and preservation of classical learning as institutionally and socially organised. The fetishisation of guoxue as a national object of desire moved in quickly to fill the void created by the collapse of classical learning. Although guoxue is incapable of designating itself by delineating and delimiting its structural scope, and as such is often invoked as a floating signifier that says more about what it is not than what it is, the very idea of guoxue has played an important role in imagining a cultural form of Chineseness in response to the narratives of modernity, reform, and development. Here, I find Foucault's discussion of the historicity of the concept of the "author" useful in its suggestion of a point of entry into the discursive function of guoxue. Foucault's author is not a person, but a name, a discursive marker, and a historical formation; it "permits one to group together a certain number of texts, define them, differentiate them from and contrast them to others." (14) Different from an ordinary noun, however, the name "author" does not just point to an individual as a person, but offers a description of a whole range of associations and relations.

Like the name author, the term guoxue is "situated between the two poles of description and designation," (15) and it attempts to designate its constitutional legitimacy by presenting itself as a descriptive category that envelops all branches of learning defined as Chinese. Invoking the idea of a master system of Chinese knowledge, guoxue acts as an instrument of organisation for the development and consolidation of national consciousness in the form of everyday practice of learning and scholarship. It pushes out a discursive space in which intellectual authenticity may be confirmed and re-confirmed and claims to a singular cultural past may be repeatedly made. Nowhere is the politics of guoxue more manifest than in its performance of the function of shaping and organising the public understanding of cultural and intellectual Chineseness. It would be more productive, therefore, to consider the discursive role of guoxue rather than its ontological constitution, and to examine the conditions and circumstances under which it is able to play such a role.

To recapitulate, I would draw attention to the following:

First, historically, guoxue was invented in response to the pressures created by modern Western knowledge, which began to unsettle and displace forms of classical learning in the early twentieth century. Although we are now under vastly different historical conditions, the impulse behind the forceful return of earlier efforts to construct guoxue is not radically different from the one that defined the intellectual politics of the early twentieth century. This discursive continuity is suggestive of larger and even more fundamental social forces that have shaped and defined contemporary Chinese intellectual life.

Secondly, the idea of guoxue is rooted in a belief in the singularity of national learning as a system of indigenous knowledge, and in its irreducible difference from other systems of knowledge, especially those that began to challenge and subvert its own dominance and centrality in its native domains. Although guoxue is seldom explicitly presented as exclusive of or incommunicable with other systems of knowledge, as a form of intellectual nativism, its point of reference is unequivocally Western learning, which is imagined from the outset to be its other, its rival, and its raison d'être. This is perhaps all too familiar a point, but it is worth repeating in thinking about guoxue both as an imaginary and as a powerful historical and living force in creating and disseminating a form of national consciousness in the past and at present.

Thirdly, the conceptualisation of guoxue affirms only its temporality, and it does not have an active life prior to the moment of its construction or outside the narrative in which it is staged; but as long as it is constructed or imagined as a historical formation, the idea of guoxue is nearly always seen and used as an alternative to the present, a historical model that would remedy the inadequacies of the present. At a time of major social change such as the present one in China, the mediation between "the emergent" and "the residual" can be a formidable political task. (16) While the emergent has yet to be fully grasped, the residual refuses to accept its historical telos.

\section{National literature and national language}

Outside the Euro-American world, the development of intellectual modernity has typically followed a tortuous path and is often more problematic and controversial than other aspects of modernity: it is necessary not only to identify a specific form perceived as modern for local expression, but also to enter a negotiation of that form with its pre-modern local or indigenous cultural formations and resources. In the early twentieth century, Japan offered China an example of modernisation, and its success was widely viewed as a model of development and progress. However, the question for Japanese intellectuals in the Meiji period was how to recast Japanese culture through a reduction of its subordination to Chinese influence.

In the domain of creative writing, for instance, the creation of a national literature perceived as truly Japanese would need to start with the constitution of a national language. Like Chinese, the Japanese language was non-phonetic, and the severance of speech from writing was generally seen as prohibiting the constitution and development of a Japanese literary modernity. With the rise of Japan as a military and economic power came the question of the creation and development of its cultural identity,

12. Yan Fu, "Lun jiaoyu yu guojia zhi guanxi" (On the relation between the state and education), in Yan Fu heji (Collected works of Yan Fu), Taibei, Caituan faren Gu Gongliang wenjiao jijinhui, vol. 2, 1998, 376. For a study of the Imperial Civil Examination, see Benjamin A. Elman, A Cultural History of Civil Examination in Late Imperial China, Berkeley, University of California Press, 2000.

13. Yu Ying-shih, "Shishuo keju za zhongguoshi shang de gongneng yu yiyi" (Notes on the function and meaning of Imperial Civil Examination), in Twenty-First Century (internet edition), October 2005.

14. Michel Foucault, "What Is an Author?", in Paul Rabinow (ed.), The Foucault Reader, London, Penguin Books, 1986, p. 107.

15. Ibid., p. 106.

16. These are the terms Raymond Williams uses in describing social and cultural conflicts in a society caught in the process of radical transformation. See Raymond Williams, "Dominant, Residual, and Emergent," in Marxism and Literature, Oxford, Oxford UP, 1977, pp. 121-127. 
especially with regard to language that had been derived from Chinese. In the making of a new (national) literature, nothing seems more crucial than the constitution of a set of fresh linguistic conditions - of what might be called, in Derridean terms, "phonocentric" elements in the Japanese language. Considering the role of translation in the emergence of modern Japanese literature, Naoki Sakai observes that the formation of a national literature "seems to coincide with...the emergence of vernacular phonocentrism in the conception of writing." (17) The advent of the modern Japanese novel was facilitated by efforts to minimise the distinction between written and spoken Japanese. Masao Miyoshi reminds us of the historical significance of the work carried out by the first generation of modern Japanese writers such as Bimy in the mid-nineteenth century to establish a more structural correspondence between spoken and written forms of Japanese, which is, Miyoshi says, "fundamental to our understanding of the new novel of the time and, in some important respects, to our understanding of the modern Japanese novel right up to the present." These writers' collective efforts are known as the gembun'itchi movement that aimed to establish a "correspondence between spoken and written languages." (18) The development of the modern Japanese novel, Miyoshi tells us, "is predominantly Western in impulse, as writers turned away from traditional tales and romances and actively sought new narrative forms to fit the new Age of the West." These writers followed the conventions of the realist novel established in the West, and they concentrated on "the ordinary experience of ordinary people" narrated in "a colloquial language from the average person's moral perspective." Although there were reservations about this new form of story-telling at first, the novel, "an imported art," has been slowly but "successfully naturalized." "We can say then," Miyoshi concludes, "that there exists a tradition of the Japanese novel which is formally as well as thematically recognizably 'universal,' at least in intent." (19) Universal, of course, only in the sense that the novel had been accepted and recognised as a form of creative imagination in prose first developed in the West and distinct from Japan's own narrative forms such as tales and romances, and as a genre of literary modernity adopted and naturalised in conjunction with the gembun'itchi movement. Miyoshi's sociological account of the emergence of the modern Japanese novel exemplifies the immensely complex relationship between national language and national literature at the time of Japan's great transformation. ${ }^{(20)}$

There is a remarkable parallel between modern Japanese literature and modern Chinese literature, not only in terms of the need to discover and adopt a new vernacular for them, but also in view of their acceptance of the conventions of writing first established in the West. The making of a new national literature during the May Fourth period was predicated on the success of reforming the Chinese language, specifically on the establishment of a new vernacular (baihua) as the normative form of expression and communication in writing as well as in speech. (21) The question of "national language" was part of the larger question about the possibility of a new culture of social and intellectual life that both followed and embodied the logic of modernity. The term guoyu (national language), like guoxue, was borrowed from Japanese, ${ }^{(22)}$ and it was primarily used "with reference to Western languages, just as baihua (the vernacular) is to wenyan (classical language)." (23) The word guo both defines and delimits its subject verbal unit yu (language); like guoxue, guoyu is as ambiguous as it is descriptively limiting. However, though guoyu has the same morphological formation as guoxue and might refer to a similar intellectual category per- ceived as Chinese, the intellectual impulses for their creation are different. To conceive a national language is to dethrone wenyan and to revive its suppressed oral other, baihua, by giving it a written form that must be different from wenyan, while the idea of guoxue, as mentioned above, calls for an unqualified return to what is produced and preserved in wenyan.

It is relevant to note that concurrent with the movement to revive guoxue at the present is the call for the reinstatement of traditional written characters. Although it is difficult to see the practicality of invalidating simplified characters, the formal proposal to end their use has no doubt contributed to that desire for the purity of China's linguistic culture. (24) The point is perhaps not about which system of writing is superior. Nearly a century distanced from the May Fourth language reform movement, we are bound to be less sensitive to the shared feeling of urgency for reforming the Chinese language that prevailed among progressive May Fourth intellectuals, whose notion of literary modernity was predicated on the transformation of the language, in particular the written language, into a modern system.

Fu Sinian was probably the first to argue for a Europeanised literacy in China: for a Europeanised new literature and a Europeanised national language adopting all the major linguistic features of European alphabetic languages, including their grammar, syntax, and figures of speech. (25) Like many of his contemporaries, Fu's campaign for a new writing system followed an instrumentalist logic. For him, "language is the tool of thought, and writing is the tool of speech. Precisely because it is an instrument, it should be easy to use.... We ask that wenyan be abolished and guoyu be

17. Naoki Sakai, "Distinguishing Literature and the Work of Translation: Theresa Hak Kyung Cha's Dictée and Repetition without Return," in Sakai, Translation and Subjectivity: On "Japan" and Cultural Nationalism, Minneapolis, Univ. of Minnesota Press, 1997, p. 20.

18. Masao Miyoshi, Accomplices of Silence: The Modern Japanese Novel, Berkeley, University of California Press, 1974, p. 5.

19. Masao Miyoshi, op. cit., p. ix.

20. The dissemination of the novel as a universal form of story-telling, as the genre of literary modernity, has contributed to the emergence of the concept of world literature. Franco Moretti defines world literature not as a collection or totality of disparate national literatures, but as a system within a larger world historical structure. In Moretti's formulation, world literature is at once a displacement of national literature and a dramatic enlargement of it. See Franco Moretti, "Conjectures on World Literature," New Left Review, Jan/Feb 2000, pp. 55-56.

21. Nearly half a century after the publication of his manifesto for the new cultural movement in 1916, Hu Shi reflected on the procedure of the new literature movement: "New Literature began with new poetry; the issue of new literature was one of new poetry, that is, what sort of written language it should use." See Hu Shi, "New Literature, New Poetry, and New Characters," in Hu Shi, Selected Writings on the New Literature Movement, Beijing, Zhonghua shuju, 1992, p. 280.

22. Not without some irony perhaps, the term guoyu was probably first proposed by Wu Rulun, an accomplished practitioner of the classical style of writing. During a visit to Japan in 1902, he was impressed with the work carried out by the Japanese government to promote the Tokyo dialect as its national language. Upon his return to China, Wu proposed to the Qing government that China should have its own guoyu based on the Beijing dialect. In 1909, the Qing government adopted the proposal and replaced its guanhua (official language or mandarin) with guoyu. For a review of the etymological origin(s) of guoyu, See Zhang Xiangdong, "When Was 'Guoyu' as the Translation of 'National Language' First Used in Modern China?", Hanzi wenhua (Culture of written characters), no. 6, 2008, pp. 74-76.

23. Li Jingxi, Guoyu yundong shigang (History of the national language movement), Shanghai, Commercial Press, 1935, p. 7

24. In 2009, Pan Qinglin, a member of the Chinese People's Political Consultative Conference (CPPCC), submitted his proposal that the simplified script be phased out over a period of ten years and traditional characters be restored, for the following reasons: 1. Simplified characters created in the 1950s have departed from the beauty and law of Chinese writing; 2 . The invention of computer technology made it possible to quickly and efficiently input written characters, no matter how complicated they are, and therefore has superannuated the argument that simplified characters would be easier to write and use; 3 . It would contribute to the unification of China to use traditional Chinese script as it is used in Taiwan and by overseas Chinese. This proposal has been widely reported and debated in the media and over the internet. The text of the proposal was available online at http://blog.sina.com.cn/ s/blog_64ca60180100gw1j.html (accessed 30 August 2010).

25. Fu Sinian, "Zenyang zuo baihuawen" (How to write in baihua), in Ouyang Zesheng (ed.), Fu Sinian Quanji (Collected works of Fu Sinian), Changsha, Hunan jiaoyu chubanshe, 1919, (2003), vol. 1, pp. $125-136$. 
adopted, because it is inconvenient to express thought in wenyan, and it is much easier to express it in guoyu. For the same reason, we should phoneticise written characters." (26) He prophesised in 1919 that China would follow the Japanese example and that in ten years it would witness the emergence of a new national literature written in a new vernacular. (27)

Fu's prediction came true. His cosmopolitan view of Chinese national literature was shared and practiced by younger generations of writers, and within a matter of several decades, nearly all major traditional forms of literature were either displaced or marginalised. Although the literary Europeanisation would soon come to be seen as so discordant with what had been known and accepted as the Chinese mode of expression that some modifications of "new literature" became necessary for its wider acceptability and circulation, this new literature never returned to the past and it remained Western, at least in form. Perhaps we, too, may conclude that there exists a tradition of modern Chinese literature that is formally and perhaps also thematically "universal," even though it is thoroughly sinicised, nativised, or, to use Miyoshi's word, "naturalised" for a targeted readership in China. (28)

Although a student leader in the May Fourth movement, Fu was by no means a radical revolutionary intellectual, and he would later choose to join the Nationalists. (29) The leftwing intellectuals, however, were far more radical in proposing changes to Chinese language, especially its writing. Lu Xun, for example, argued forcefully for the abolition of Chinese writing altogether, and for its replacement with an alphabetic system of writing as the necessary precondition for the nation's modernisation. ${ }^{(30)}$ Chinese Communists were quick to recognise the revolutionary elements in the proposal for an alphabetised script and embraced the radical ideology of the language reform movement. As is well-known, Qu Qiubai was committed to a new Putonghua being adopted across the country, and he devoted a substantial part of his revolutionary work and time to promoting, teaching, and practicing the Latinised written script. (31) This is no place to discuss technical details of reforming the Chinese language, such as the debates on which alphabetic/phonetic system should be adopted, the Latinxua or the National Language Romanisation (Gwoyeu Romatzyh), which often culminated in ideological division between leftwing intellectuals and their counterparts in the Nationalist camp. ${ }^{\text {(32) }}$ More pertinent are the changes language reform would bring to some of the most fundamental social relations in Chinese society.

In the early 1930s, about the same time Latinxua was formalized in Shanghai, Gramsci noted in his prison cell in Turin that when the question of language became the focus of public attention, it was indicative of other problems such as "the formation and enlargement of the ruling class, the need to stabilize the most intimate and secure links between that ruling group and the popular national masses." (33) Gramsci was concerned with the role of intellectuals in the process of nation-building, and he was convinced that "the relation between the intellectuals and the people-nation" could be best "studied in terms of the language written by the intellectuals and used among them." (34) Gramsci's reflections on the status of literary Latin prior to the constitution of vernacular Italian as the national language of Italy is suggestive of a useful socio-historical perspective on Chinese classical writing (wenyan) and its linguistic hegemony for thousands of years. "Literary Latin," writes Gramsci, "crystallizes into the Latin of scholars, of the intellectuals .... In no way can it be compared to a spoken, national and historically living language." The separation between literary Latin and everyday use of language, between writing and speech, extends into a "split between the people and the intellectuals, between the people and culture." (35) Despite, or perhaps because of, its restricted use by a minority of scholars and intellectuals, literary Latin's hegemony was firm and secure.

Though literary Latin and Chinese classical writing are products of separate and un-related historical conditions, the similarities I attempt to suggest here are nevertheless not fortuitous. Like literary Latin, wenyan was not a spoken language, that is, not a living everyday language, but a language of the privileged - of scholars and bureaucrats - and as such it could never be truly a language of the people and therefore of the nation. "The vernaculars are written down when the people regain importance," Gramsci observes. ${ }^{(36)}$ A national language must be one of the masses, not of a minority of elites, and the proper role of progressive intellectuals would be to facilitate the emergence of such a language of the people as national language.

In the grand narrative of Western modernity, the notions of national language and nationalliteratur emerged in conjunction with the historical change of the meaning, grammar, and morphology of the word "culture", from a non-countable noun to a countable one, a change that made possible the idea of national culture as singular and bound to the physical environment of the place with which it was associated. (37) As is well known, Herder played a decisive role in pluralising the idea of culture. What distinguishes one nation from another is what constitutes the sources of that nation's identity. National language and national literature are organically rooted in folk culture. Shakespeare was exemplary of folk genius, and through translation Shakespeare was incorporated into the canon of German literature in the closing decade of the eighteenth

26. Fu Sinian, "Hanyu gaiyong pinyinwenzi chubutian" (Preliminary thoughts on the phoneticisation of Chinese," in Fu Sinian quanji (Collected works of Fu Sinian), vol. 1, p. 161. Qian Xuantong called this essay the first call to arms for reforming written Chinese. See Qian Xuantong, "Hanzi geming" (The revolution of written Chinese characters), in Qian Xuantong, Qian Xuantong wenji (Collected works of Qian Xuantong), Beijing, People's UP, 1999, vol. 3, p. 62.

27. Fu Sinian, "Zenyang zuo baihuawen," p. 136.

28. See Luo Zhitian, Libian zhong de chuancheng (Continuities in the radical transformations), Beijing, Zhonghua shuju, 2003, p. 270.

29. Fu led three thousand Beida students to the diplomatic compounds in Beijing on 4 May 1919, "to present a protest letter to the American ambassador," which was seen to be the moment signifying the outbreak of the May Fourth student movement. See Wang Fan-sen, Fu Ssu-nien: A Life in Chinese History and Politics, p. 31.

30. Lu Xun argued that ideographic writing was the language of scholars and social elites, not of the people: "The opposition between the written script and the masses is irreconcilable." He attributed widespread illiteracy among the poor to written characters and argued for the adoption of a system of alphabetic writing. See Lu Xun, "Letter to Cao Juren" (2 August 1934), in Lu Xun Quanji (Complete works of Lu Xun), Beijing, Renmin wenxue chubanshe, 1991, vol. 6, p. 76.

31. For details of his new writing, see Qu Qiubai, "New Chinese Writing: A Proposal," in Qu Qiubai wenji (Collected writings of Qu Qiubai), Beijing, Renmin wenxue chubanshe, 1953, vol. 3, pp. 705-851.

32. There have been copious studies of the language reform in the late nineteenth and early twentieth centuries. For an overview of the historical efforts to reform the Chinese language, see : Li Jingxi, Guoyu yundong shigang (History of the national language movement), Shanghai, Commercial Press, 1935; Ni Haishu, Zhongguo pinyin wenzi yundong shi jianbian (A brief history of alphabetic writing in China), Shanghai, Shidai shubao chubanshe, 1948. For a discussion of the 'leftwing intellectuals' work on Latinised writing, see John DeFrancis, Nationalism and Language Reform in China, New York, Octagon Books, 1950; and Ni Haishu, Ladinghua xinwenzi gailun (An introduction to new Latinised writing), Shanghai, Shidai chubanshe, 1949. More recently, Elisabeth Kaske's The Politics of Language in Chinese Education, 1895 - 1919 (Leiden and Boston, Brill, 2008), offers a historical discussion of language reform in the republican period.

33. Antonio Gramsci, "Notes for an Introduction to the Study of Grammar," quoted in Elizabeth Horodowich, Language and Statecraft in Early Modern Venice, Cambridge UP, 2008, p. 1.

34. Antonio Gramsci, Selections from Cultural Writings, David Forgacs and Geoffrey Nowell-Smith (eds.), W. Boelhower (trans.), Cambridge, Mass., Harvard UP, 1985, p. 167.

35. Cramsci, Selections from Cultural Writings, op. cit., p. 168.

36. Ibid.

37. See Raymond Williams, "Culture," in Marxism and Literature, op. cit., pp. 11-20. 
century. ${ }^{(38)}$ Herder's elaborations on national culture, national language and national literature are generally considered the beginning of modern nationalism. ${ }^{(39)}$

Literature, as in "national literature," is not just a descriptive category, but an evaluative one. In the later eighteenth century, when literature developed into a specialised form of imaginative writing, and into a category larger than poetry, it was at the same time going through a process of selfselection for the establishment of a canon of the most representative examples of the national literary tradition. Only "a critically established minority of 'canonical' texts" would be included. (40) The canonisation of the national literary tradition was crucial for the rise of the concept and practice of nationalliteratur, and for its specialisation, which would be fundamental to the subsequent establishment of national studies. ${ }^{(41)}$

Writing of the rise of English Studies, Raymond Williams observes: "Selectivity and self-definition... were ... projected as 'literature' itself, as 'literary values' and even finally as 'essential Englishness': the absolute ratification of a limited and specializing consensual process." (42) This process of canonisation, mediated by the practice of literary criticism, not only regulated literary practice and normalised "good" taste for writing, but also developed and consolidated a consensus over English guocui - "the essence of Englishness" - as represented and recorded in the words of its canonised authors. ${ }^{(43)}$

\section{The dilemma of third-world culture}

The development of national literature and national language in China followed a different ideological impulse. Rather than a reassertion or reaffirmation of essential Chineseness, the envisioning of a new (national) literature and national language presupposed the liquidation of their traditional and indigenous predecessors: the making of national literature and language must, so to speak, first be de-nationalised in order to identify and adopt more universal forms and modes of expression and representation. The cosmopolitan impulse behind the collective efforts to create a new national literature written in a vernacular Putonghua is in stark contrast with the nativist ideology underlying guoxue. I would suggest that this contrast is symptomatic of a radical historical contradiction that thirdworld intellectuals must address in the process of nation-building and modernisation: the need to mediate between indigenous cultural formations and those brought into being through the operation and dissemination of the culture of global capitalism. No doubt, the damage the latter did to the former is cause for a political and moral critique of expansionist capitalism in advancing a global capitalistic modernity, but the logic of modernity worked the way it did, and it should be understood historically. In non-European-capitalistic societies, the process of modernisation is typically one of disintegration, disruption, and discontinuity, one in which the present emerged as an irreconcilable other of the past. Whether to accept this historical process or to resist it by devising an alternative modernity lies at the source of a genuine historical contradiction.

Alternative modernity is as problematic as it is appealing, espousing an imbedded ambivalence towards modernity itself, "alternative" because of its implicit reservations about, if not rejection of, modernity as universal beyond cultural and national boundaries. A typical third-world response to the Euro-American model of modernity is an inward return to the past for rediscovery and retrieval of national heritage in the service of the present and the future, as a counterbalance to global capitalistic modernity and perhaps as a consolation to the anxieties created by the very process of modernisation. Conceptualisation of alternative modernity therefore often ends in the archaeology of an indigenous past. This well-established pattern and "political impulse to recover traditional cultural resources to resist the pretentions of a supposedly universal 'modernization' sprung from the West" may be found "in the colonial, semi-colonial or... just non-Western world... from Ireland to Turkey, Peru to Iran, India to Japan." (44) Just as this pattern needs to be understood historically, resistance to such a political impulse should likewise be considered part of third-world societies' struggle for the conceptualisation and constitution of a modernity as different from, and yet comparable to, the capitalistic model of modernity.

Reflecting on the historical necessity of the discontinuities between India's pre-colonial tradition and its post-colonial modernity, E.M.S. Namboodripad has this to say:

Indian society had, for several centuries, remained in a stage of stagnation and decay; its destruction had come as the order of the day. However, since there were no internal forces which could destroy the stagnant and decaying old society, the external force that appeared on the scene, the European trading bourgeoisie who came to India in the fifteenth and sixteenth centuries, particularly the most modern and powerful of them, the British trading-cum-industrial bourgeoisie, were the "unconscious tools of history."... This destruction of the old society which had come on the agenda and was being carried out by the foreign occupiers will surely be followed by the construction of a new society. ${ }^{(45)}$

For Namboodripad, therefore, the assault on the local, on the indigenous, and on India's pre-colonial resources is nothing but a progressive develop-

38. Herder's celebration and appropriation of Shakespeare is vividly recorded in his essay on Shakespeare (see Johann Cottfried Herder, Shakespeare, trans. Gregory Moore, Princeton and Oxford, Princeton UP, 2008). For an informative overview of Shakespeare in Germany, see lan Buruma, "Goethe's Shakespeare," in Voltaire's Coconuts, London, Weidenfeld \& Nicolson, 1999; for a recent critical and scholarly study of the German reception of Shakespeare, see Roger Paulin, The Critical Reception of Shakespeare in Germany 1682 - 1914: Native Literature and Foreign Genius, Hildesheim, Zürich, and New York, Georg Olms Verlag, 2003.

39. Herder is believed to have coined the word Nationalismus. See Isaiah Berlin, Three Critics of the Enlightenment: Vico, Hamann, Herder, Henry Hardy (ed.), Princeton and Oxford, Princeton UP, 2000, p. 206. OED records the first appearance of the word in English in 1798.

40. Raymond Williams, "Crisis in English Studies," Writing in Society, London, Verso, 1983, p. 193.

41. In the nineteenth century, as Raymond Williams observes, English Literature was generally understood in Britain as "a national literature," "distinct from the earlier classical and European emphases," and English studies at the schools included "the literature and the language of this self-conscious and consciously taught nation." Raymond Williams, "Cambridge English, Past and Present," Writing in Society, p. 179.

42. Williams, Marxism and Literature, op. cit., p. 52.

43. In the institutional history of English Studies, Cambridge English has an iconic status. But it was not formally set up until 1917. Till the mid-nineteenth century, the only Triposes had been in Mathematics and Classics, and then came Moral and Natural Sciences, followed by Theology, Law, and History, none of which was national studies. English studies featured under the category of the Modern languages. The process of building and consolidating the consensus over "essential Englishness" through the canonisation of English national literature was part of Britain's imperial project in the nineteenth century. Prior to its establishment in England, English Studies had been employed as a cultural instrument of conquest in its colonies, such as India. Pedagogically defined and institutionally promulgated, English Studies effectively formalised the Empire's national literature and national language abroad. For a discussion of English Studies as a discipline in Britain, see Williams, "Cambridge English, Past and Present," in Writing in Society and "The Future of 'English Literature,"' in What I Came to Say, London, Hutchinson Radius, 1989; see also Terry Eagleton, "The Rise of English," Literary Theory: An Introduction, Oxford, Blackwell, 1983. Gauri Viswanathan's Masks of Conquest: Literary and British Rule in India (New York, Columbia UP, 1989) offers a critical narrative of English Studies in India.

44. See Zhang Yongle, "The Future of the Past: On Wang Hui's Rise of Modern Chinese Thought," New Left Review, March/April 2010, p. 48

45. E.M.S Namboodripad, "Evolution of Society, Language and Literature in India," Social Scientist, vol. 8, no. 9, 1980, pp. 4-5. 
ment that should be historically comprehended, even though it was necessitated by external forces, namely, modern Western practice established by trading capitalism. Mutatis mutandis, progressive May Fourth intellectuals would have said the same thing about the sudden disruption and disjunction that occurred in the early twentieth century in China. This historicist view on the discontinuities of history and on the historical necessity of these continuities is developed from what Namboodripad calls "the essence of Marxism." After the arrival of the British colonialists, the Indian people, Marx claims, "lost their old world without gaining the new." (46) While fully sympathetic towards them for their suffering, Marx was not sentimental about questions of justice and equality. Namboodripad likewise regards the destruction of traditional India as an inevitable and necessary historical development by the forces of change from without, many of which were ethically deficient. Those "unconscious tools of history" enabled Indian society to undergo the reluctant process of transformation, and even though they created at the same time misery and suffering for the Indian people, Marx did not shed a single tear at the destruction of old India society. Neither did Namboodripad.

Divergent views on the choice of the model of modernity, especially in a former colony such as India, often reflect "a particular contradiction in the cultural logic of colonial capitalism" that has not only made possible "a certain democratization of language, some secularization of ideological parameters, some denting of insularity," but also created "a dominant intelligentsia which merely oscillates between ideological dependence on the fabrications and sophistries of advanced capitalism on the one hand, and indigenist, frequently obscurantist nostalgia on the other." (47) China has not been a colony, but Chinese intellectuals are perhaps not exempt from a contradiction such as that created by the process of decolonisation of India. As a national movement, a state project, the revival of guoxue is an organised response to the dominant language of Western modernity by urging a return to the past, however fluid and intractable that past might be. Noticeable within the discourse of national learning is the state support of the establishment of Confucius Institutes in strategic locations around the world. According to the "Constitution and By-Laws of the Confucius Institutes," these institutes intend to enhance "understanding of the Chinese language and culture" by "people from different countries" and to promote "the development of multi-culturalism, and to construct a harmonious world." (48) In the name of multiculturalism, therefore, classical learning is deployed strategically to diversify our cultural experience in the process of globalisation. The call for the constitution of "national learning" in the context of China's ascendency on the global scene has a special appeal, a multiculturalist one that presents itself as a force of resistance to the singularity of Western modernity. Admittedly, the impulse behind the idea of guoxue is more scholarly and intellectual than political and ideological, and discursive work on its construction is mostly carried out within the academy. But the involvement of sustained scholarly labour is responsible for the practice of an academic culture of nostalgia, self-indulgence, and snobbery. In the end, the call for the constitution of guoxue is not so much about national learning as such, or about whether the development of China's soft power would require its constitution, as it is about those who advocate and promote guoxue as a structure of knowledge distinct from other systems of learning, especially modern scientific knowledge, and about their belief in its function as a means of self-assertion either on behalf of a local institutional establishment they belong to or in the name of the nation as a whole. Just where this grand torrent of guoxue will take the country is a question as open as the question of China's future.
46. Ibid., p. 5 and 2.

47. Aijaz Ahamad, In Theory: Classes, Nations, Literature, London, Verso, 1992, p. 240. Arif Dirlik's critique of the politics of post-colonialism is advanced in a broader theoretical context for considering the dilemmas, contradictions, and responsibilities of third-world intellectuals in the new global system. See Arif Dirlik, The Postcolonial Aura: Third World Criticism in the Age of Global Capitalism, Boulder, Westview Press, 1997, especially Chapter 2, "Culturalism as Hegemonic Ideology and Liberating Practice"; and Postmodernity's Histories: The Past as Legacy and Project, Lanham, Rowman \& Littlefield, 2006.

48. See "Constitution and By-Laws of the Confucius Institutes," (available online at http://english.hanban.org/node_7880.htm\#n01, 3 September 2010). If the Confucius Institute has an unconcealed political objective, the revival of ruxue or Confucianism has been a collaborative intellectual project collectively undertaken by scholars from Chinese-speaking academic communities. Since the mid-1980s, Taiwan and mainland China, for example, "have witnessed the most sustained resurgence of academic and intellectual interest in ruxue - variously conceived as a form of culture, an ideology, a system of learning, and a tradition of morally normative values - of the past century" (John Makeham, Lost Soul: "Confucianism" in Contemporary Chinese Academic Discourse, The Harvard University Asia Center for the Harvard-Yenching Institute, 2008, p. 1). Arif Dirlik argues that "the Confucian revival is best viewed as a manifestation in East Asia of a global postcolonial discourse." Arif Dirlik, "Confucius in the Borderlands: Clobal Capitalism and the Reinvention of Confucianism," Boundary 2, vol. 22, no. 3, Autumn 1995, p. 230 